\begin{tabular}{|l|l|l||}
\hline \multicolumn{2}{|c|}{ PublisherInfo } \\
\hline \hline PublisherName & $:$ & BioMed Central \\
\hline \hline PublisherLocation & $:$ & London \\
\hline \hline PublisherImprintName & $:$ & BioMed Central \\
\hline \hline
\end{tabular}

\title{
Antigen induced NO in asthmatic airways
}

\begin{tabular}{|c|c|c|}
\hline \multicolumn{3}{|c|}{ ArticleInfo } \\
\hline ArticleID & : & 1605 \\
\hline ArticleDOI & : & 10.1186/rr-2001-68506 \\
\hline ArticleCitationID & : & 68506 \\
\hline ArticleSequenceNumber & $\sigma^{\circ}$ & 16 \\
\hline ArticleCategory & $:$ & Paper Report \\
\hline ArticleFirstPage & : & 1 \\
\hline ArticleLastPage & : & 4 \\
\hline ArticleHistory & : & $\begin{array}{ll}\text { RegistrationDate } & : \text { 2001-9-14 } \\
\text { Received } & : \text { 2001-4-26 } \\
\text { OnlineDate } & : 2001-9-14\end{array}$ \\
\hline ArticleCopyright & $:$ & Biomed Central Ltd2001 \\
\hline ArticleGrants & 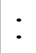 & \\
\hline ArticleContext & : & 129312211 \\
\hline
\end{tabular}


Alaina Ammit, ${ }^{\text {Aff1 }}$

Corresponding Affiliation: Aff1

Aff1 University of Sydney, Australia

\section{Keywords}

Antigen, asthma, nitrate, nitrite, NO, S-nitrosothiols

\section{Context}

Exhaled nitric oxide (NO) levels are elevated in asthma and other inflammatory lung diseases. Using repeated noninvasive monitoring, it has been suggested that NO is a marker of airway inflammation, but that it may have both anti-inflammatory and proinflammatory effects. The aim of this study was to investigate NO chemical events in the human airway during immediate and late antigen-induced asthmatic responses.

\section{Significant findings}

At baseline, and immediately after challenge, NO in asthmatics tended to be higher than in controls. After $48 \mathrm{~h}$ NO increased twofold in asthmatics but not in controls. Nitrite levels increased immediately after antigen challenge in asthmatics but not in controls, and had doubled by $48 \mathrm{~h}$. In contrast, nitrate was unaffected by challenge at these time points. Interestingly, at baseline, or immediately after segmental antigen challenge, levels of $S$-nitrosothiols in asthmatic airways were lower than those found in healthy controls. However, $S$-nitrosothiol levels increased during the late response to those levels found in healthy controls. The loss of epithelial cells in asthmatic airways hindered accurate quantification of nitrotyrosine in these cells, although a tendency toward more intense staining for nitrotyrosine in the asthmatic epithelium, as compared with the control, was noted. The authors concluded that the dynamics of NO metabolism during an asthmatic response reveal multiple and sequential reactions, suggesting a multifunctional role for NO in the airway.

\section{Comments}


This paper suggests several biologic functions for NO in the asthmatic airway. NO rapidly consumes cytotoxic reactive oxygen species produced during the immediate asthmatic response (see Addistional information [1]), leading to accumulation of the innocuous product nitrite. This immediate detoxification role is supported by animal models, in which inhibition of NO synthesis leads to a more severe toxic reaction to antigen challenge (see Additional information[2]). Nitrosylation reactions predominate during the late asthmatic response, with accumulation of $S$-nitrosothiols, proposed as safe reservoirs for removal of toxic NO derivatives (see Additional information [3]). Another recent publication has confirmed an elevated concentration of $S$-nitrosothiols in exhaled breath condensate of asthmatics (see Additional information [4]). Although NO may have some harmful effects in the airways, these results show a temporal sequence of NO participation in asthmatic airway chemical events, and suggests a protective role for $\mathrm{NO}$ reaction products in the asthmatic response.

\section{Methods}

Segmental antigen challenge, immunohistochemistry, chemiluminescent analyzer, endobronchial biopsies, BAL

\section{Additional information}

1. Sanders SP: Nitric oxide in asthma. Pathogenic, therapeutic, or diagnostic?

Am J Respir Crit Care Med 1999, 21:147-149.

2. Mehta S, Lilly CM, Rollenhagen JE, Haley KJ, Asano K, Drazen JM: Acute and chronic effects of allergic airway inflammation on pulmonary nitric oxide production.

Am J Physiol 1997, 272:L124-L131.

3. Gaston B, Sears S, Woods J, Hunt J, Ponaman M, McMahon T, Stamler JS: Bronchodilator Snitrosothiol deficiency in asthmatic respiratory failure.

Lancet 1998, 351:1317-1319.

4. Corradi M, Montuschi P, Donnelly LE, Pesci A, Kharitonov SA, Barnes PJ: Increased nitrosothiols in exhaled breath condensate in inflammatory airway diseases.

Am J Respir Crit Care Med 2001, 163:854-858. 


\section{References}

1. Dweik RA, Comhair SAA, Gaston B, Thunnissen FBJM, Farver C, Thomassen MJ, Kavuru M, Hammel J, Abu-Soud HM, Erzurum SC: NO chemical events in the human airway during the immediate and late antigen-induced asthmatic response. Proc Natl Acad Sci USA . 2001, 98: 2622-2627.

This PDF file was created after publication. 